\section{DIGITAL MARKETING UNTUK \\ KEWIRAUSAHAAN PESANTREN DI MASA PANDEMI COVID-19}

Agata Iwan Candra*, Hendy, Herlan Pratikto, April Gunarto, Sumargono

Teknik Sipil, Universitas Kadiri

$\begin{array}{lll}\text { Article history } & \\ \text { Received } & \text { : } & 24-09-2020 \\ \text { Revised } & : & 19-12-2020 \\ \text { Accepted } & : & 04-01-2021\end{array}$

\section{*Corresponding author}

Agata Iwan Candra

Email: iwan_candra@unik-

kediri.ac.id

\begin{abstract}
Abstrak
Pondok Pesantren El Faws Pagu Kediri tergolong pesantren baru yang memiliki misi kedepan untuk ikut serta membangun generasi muda Islam yang memegang teguh Al-Qur'an sebagai pedoman hidup. Guru pondok bercita-cita agar pesantren El Faws kelak menjadi tempat menimba ilmu pengetahuan baik ilmu agama maupun ilmu sains, teknologi, dan kewirausahaan. Akan tetapi, sekarang ini dunia sedang dilanda musibah pandemi covid-19 yang mempengaruhi perekonomian termasuk perekonomian para santri. Oleh karena itu, perlu adanya upaya yang dilakukan untuk meningkatkan minat, membuka pola pikir santri, dan masyarakat sekitar lingkungan pondok tentang kewirausahaan dengan menggunakan digital marketing di era pandemi covid-19 yang dapat membantu perekonomian para santri. Metode yang digunakan adalah metode pelaksanaan, yaitu tahap persiapan, tahap input, dan tahap proses. Kegiatan pengabdian diawali dari sosialisasi, pemberian kuisioner, praktek cara memfoto produk yang baik, dan pembuatan watermark foto produk. Para santri di pondok pesantren mendukung semua kegiatan. Hasil dari kegiatan tersebut berupa toko online yang dibuat oleh pengurus dan santri guna meningkatkan perekonomian para santri. Toko online dibuat di Shopee dan Bukalapak.
\end{abstract}

Kata Kunci: Digital Marketing; Kewirausahaan; Marketplace; Pesantren

\begin{abstract}
Pondok Pesantren El Faws Pagu Kediri is a new Islamic boarding school with a future mission to participate in building a young generation of Muslims who adhere to the Al-Qur'an as a way of life. Pondok pesantren teachers aspire that the El Faws Pondok Pesantren will become a place to gain knowledge, both religious and scientific, technology, and entrepreneurship. However, the world is currently being hit by the Covid-19 pandemic, which affects the economy, including the economy of the santri. Therefore, it is necessary to increase interest and open the mindset of students and the community around the pesantren about entrepreneurship by using digital marketing in the era of the Covid-19 pandemic, which can help the economy of the students. The method used is the method of implementation, namely the preparation stage, the input stage, and the process stage. The service activities began with socialization, giving questionnaires, practicing how to take good product photos, and making product photo watermarks. The students at the pesantren support all activities. The result of these activities is in the form of an online shop created by the board of pesantren to improve the economy of the santri. Online shop created in Shopee and Bukalapak.
\end{abstract}

Keywords: Digital Marketing; Entrepreneurship; Marketplace; Pesantren

\section{PENDAHULUAN}

Pondok Pesantren merupakan lembaga pendidikan Islam tertua yang merupakan produk budaya Indonesia asli (Jalal \& Aziz, 2017). Keberadaan Pesantren di Indonesia dimulai sejak Islam masuk negeri ini, dengan mengadopsi sistem pendidikan keagamaan yang telah lama berkembang. Pondok pesantren diakui memiliki andil yang sangat besar terhadap perjalanan sejarah bangsa Indonesia. Kediri, layak untuk mendapatkan sebutan Kota Santri, selain Kota Jombang. Hal ini dikarenakan di Kediri, terdapat Pondok Pesantren besar dan kemudian diikuti lahirnya pesantrenpesantren baru di Kota Kediri. Pondok Pesantren El Faws Pagu Kediri tergolong pesantren baru yang memiliki misi kedepan untuk ikut serta membangun generasi muda Islam yang memegang teguh AlQur'an sebagai pedoman hidup. Letak pondok pesantren El Faws adalah di Jl. Kartini Sitimerto, RT 4, RW 2, Pagu, Kediri, Jawa Timur. Letaknya yang ber- 
dekatan dengan Toko Pakaian Sama Jaya 2 yang sudah terkenal dan biasa dipadati pengunjung saat bulan Ramadhan dan menjelang lebaran, menjadikan pondok pesantren ini memiliki peluang yang cukup besar dalam mengembangkan kewirausahaan pesantren.

Di Pondok Pesantren El Faws, berdasarkan dialog dengan pengurus Pondok Pesantren yaitu Ustadz Kamto dan dialog dengan beberapa santri, bahwa mereka sebenarnya juga sangat termotivasi untuk berwirausaha dan haus akan ilmu marketing khususnya online marketing, yang diharapkan dapat menunjang kehidupan mereka setelah lulus dari pendidikan pondok pesantren. Selain itu, mereka dapat memulai ide wirausaha mereka sedari dini di dalam pondok pesantren (Syafe'i, 2017). Ilmu-ilmu yang dibutuhkan sebagai bekal hidup para santri setelah keluar dari pondok.

Entrepreneurship menurut Instruksi Presiden Republik Indonesia (INPRES) No. 4 Tahun 1995 adalah semangat, sikap, perilaku dan kemampuan seseorang dalam menangani usaha atau kegiatan yang mengarah pada upaya mencari, menciptakan, menerapkan cara kerja, teknologi serta produk baru dengan meningkatkan efisiensi dalam rangka memberikan pelayanan yang lebih baik untuk memperoleh keuntungan yang lebih besar. Sekarang ini dunia sedang dilanda musibah yaitu pandemi Covid-19 yang mempengaruhi perkembangan ekonomi global dan mempengaruhi perekonomian masyarakat (Wang, 2020). Pandemi covid-19 membuat perubahan lingkungan dalam sejarah pemasaran modern, yang berdampak besar pada sosial perusahaan responsivitas (CSR), etika konsumen, dan filosofi pemasaran dasar (He \& Harris, 2020). Dampak dari covid-19 sangat dirasakan di dunia ekonomi dan tindakan jarak sosial secara global (He \& Harris, 2020). Pemasaran elektronik seperti perangkat seluler, produk pintar, dan kecerdasan buatan lainnya termasuk konsep digital yang lebih luas di pemasaran yang mencakup semua lembaga untuk berkomunikasi dan menyampaikan nilai bagi pelanggan (Herhausen et al., 2020). Pandemi Covid memaksa kegiatan pemasaran dilakukan secara digital tanpa harus bertatap muka antara penjual dan pembeli. Hal ini yang menjadi latar belakang dilakukannya program pengabdian masyarakat ini.

Beberapa kegiatan pengabdian serupa telah dilakukan sebelumnya, diantaranya pemberian wawasan, ilmu yang berhubungan dengan digital marketing, serta inspirasi pada masyarakat Desa Sayang, Kecamatan Jatinangor (Susanti, 2020). Selain itu, pada kegiatan pengabdian yang dilakukan Farell et al. (2019)telah dilakukan sosialisasi dan pelatihan pemanfaatan digital marketing dalam pengembangan pemasaran dan kewira- usahaan UKM di Kota Sawahlunto. Kegiatan ini fokus pada upaya menghasilkan cara pemasaran dari sebuah produk hasil pemanfaatan bahan yang ada di sekitar masyarakat. Kegiatan pengabdian serupa lainnya bertujuan untuk memahamkan masyarakat akan pentingnya media internet pada zaman sekarang sebagai media saing usaha (Faris et al., 2018). Pada kegiatan pengabdian yang dilakukan oleh tim Fakultas Teknik Universitas Kediri yang terdiri dari dosen dan mahasiswa ini bertujuan untuk meningkatkan minat dan membuka pola pikir santri dan masyarakat sekitar lingkungan pondok tentang kegiatan kewirausahaan dengan mengoptimalkan digital marketing, terutama di era pandemi covid19. Dengan adanya kegiatan ini, diharapkan dapat meningkatkan pendapatan sehingga dapat memperbaiki perekonomian santri maupun pengurus pondok.

\section{METODE PELAKSANAAN}

Program ini dirancang untuk membuka pemikiran para santri, pengasuh pondok, dan lingkungan sekitar pondok tentang peluang bisnis di era digital dan masa pandemi ini sehingga memberikan dorongan untuk membuka atau mengembangkan usaha yang dapat dirintis secara mudah tanpa adanya interaksi secara langsung antara penjual dan pembeli. Dari hasil mengidentifikasi permasalahan yang ada, tim pengusul menggunakan metode pelaksanaan, yaitu tahap persiapan, tahap pelaksanaan dan tahap evaluasi. Pada tahap persiapan, tim pengabdian masyarakat yang terdiri dari dosen dan mahasiswa, melakukan survei lokasi, perizinan dan pembagian kuisioner kepada para santri untuk mengetahui minat terhadap kewirausahaan. Pada tahap pelaksanaan, tim melakukan sosialisasi yang memiliki beberapa materi yaitu sosialisasi materi digital marketing, materi sosialisasi bukalapak, sosialisasi pembuatan foto produk dan pembuatan watermark. Kegiatan dilanjutkan dengan kegiatan pelatihan pembuatan watermark dan foto produk oleh para santri. Para santri membuat lapak online sendiri. Jika masih ada kesulitan, bisa dibahas melalui grup whatsapp yang dibuat untuk bimbingan secara online.

\section{PEMBAHASAN}

Pada tahap persiapan, tim melakukan perizinan awal dan survei lokasi di Pondok Pesantren El Faw's, pada hari senin, 10 Agustus 2020 (Gambar 1). Pada tahap ini juga dilakukan yaitu pembagian kuisioner pada Selasa, 11 Agustus 2020. Hasil kuisioner menunjukkan sebanyak $22.2 \%$ santri putri sudah pernah berjualan online, sedangkan sisanya yaitu $77.8 \%$ belum pernah berjualan online. Sebanyak $8.3 \%$ santri putra sudah pernah berjualan online, sedangkan sisanya $91.7 \%$ belum pernah 
berjualan online. Disamping itu, dari data yang berhasil dikumpulkan oleh tim, diketahui bahwa sebanyak $94.4 \%$ santri putri belum mempunyai rekening tabungan dan hanya sebanyak $5.6 \%$ sisanya yang sudah mempunyai rekening tabungan. Sedangkan pada santri putra belum ada yang memiliki tabungan. Hal ini penting untuk di data karena dalam menjalankan bisnis online, kepemilikan rekening tabungan adalah mutlak diperlukan. Dari hasil rekap kuesioner juga diketahui bahwa produk-produk yang diminati santri putri untuk dijual adalah produk aksesoris, makanan, kosmetik, bantal guling, kitab dan buku, serta pakaian dan hijab. Sementara itu, produk-produk yang diminati oleh santri putra untuk dijual adalah produk tanaman, makanan, aksesoris, pakaian, kosmetik, serta perlengkapan olahraga. Pada pelaksanaannya, kegiatan digital marketing yang dilakukan di pondok El Fawz menjual produk-produk tanaman dan bibitnya, yang juga dibudidayakan di lingkungan pondok.

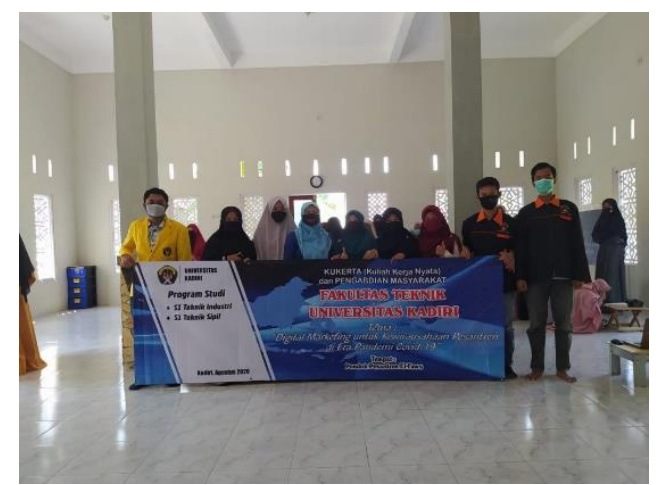

Gambar 1. Tim pengabdian (dosen dan mahasiswa FT) dengan pengurus dan santri pondok El Fawz

Tahap pelaksanaan dilakukan beberapa kegiatan yaitu pelatihan digital marketing, pengambilan photo produk, pendampingan melalui grup whatsapp, dan pendampingan dan cek berkala perkembangan akun online

\section{Pelatihan Digital Marketing}

Kegiatan pelatihan digital marketing dihadiri 40 orang, yang terdiri dari santri putri, santri putra, pengurus pondok dan yayasan. Ada tiga orang mahasiswa fakultas teknik yang dilibatkan yaitu Arjuna Rafiasta, Yuda Maulana dan Zunon Alkaf. Pelatihan digital marketing ini terdiri dari tiga tahap yaitu: Tahap pertama berupa Pengenalan digital marketing. Pada tahap ini disampaikan materi dasar digital marketing seperti pengenalan digital marketing, keunggulan dan kelemahan digital marketing, jenis digital marketing, manfaat dan juga strategi digital marketing (Luc et al., 2020). Dari kegiatan ini terlihat bahwa penyampaian materi digital marketing bagus sebagai pemahaman awal yang perlu para santri ketahui jika masuk ke dunia kewirausahaan (Purwana et al., 2017). Tahap selanjutnya, tim pengabdian fokus pada pengenalan marketplace bukalapak, yaitu bagaimana cara membuka sebuah toko online di Bukalapak. Banyak dari para santri yang kurang mengetahui apa itu aplikasi bukalapak, oleh karena itu pemateri memberikan bahan materi tentang bukalapak. Isi dari materi sosialisasi bukalapak yaitu tutorial tentang cara menginstal aplikasi bukalapak, cara membuat akun buka lapak, dan juga cara berjualan dengan menggunakan aplikasi bukalapak. Cara mengunggah konten penjualan di bukalapak, bagaimana cara melakukan transaksi penjualan di marketplace tersebut. Tahap ketiga yaitu pelatihan pembuatan gambar produk dan pembuatan watermark. Pada tahap ini peserta diajarkan estetika untuk bisa meningkatkan harga jual suatu barang. Fokus utama kegiatan ini dilakukan untuk menjamin otentisitas produk yang dijual santri maupun pengasuh pondok, diharapkan dapat menjamin kepercayaan pembeli menggunakan teks maupun simbol dalam foto sample produk mereka (Rahman \& Mawardi, 2017). Tim pengabdi memberikan pelatihan menggunakan aplikasi PicsArt bagi santri dan pengasuh pondok untuk menciptakan watermark. Pada tahap ini peserta juga diajarkan cara membuat logo atau merk. Produk harus memiliki logo atau nama merek agar pembeli tertarik dengan produk yang dijual (Agustin \& Hellianto, 2020). Kegiatan ini dilakukan pada hari Selasa, 18 Agustus 2020 dengan tetap mematuhi protokol kesehatan (Gambar 2).

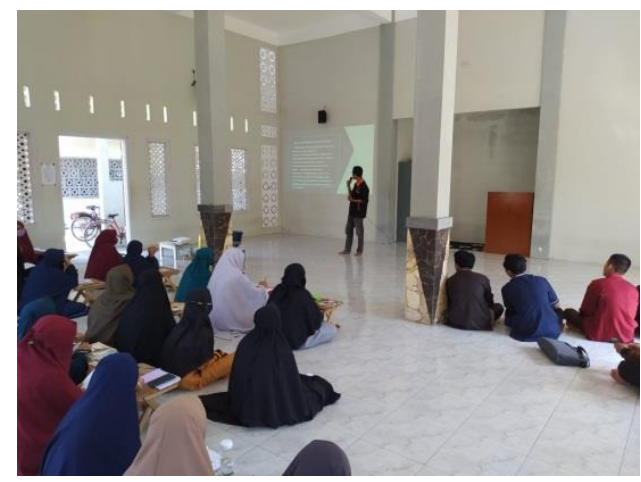

Gambar 2. Kegiatan pelatihan digital marketing dan praktek menggunakan marketplace melalui android

\section{Pelatihan Pengambilan Foto Produk}

Setelah melakukan pelatihan digital marketing tim pengabdian melakukan pelatihan pengambilan foto produk siap jual untuk dipasarkan di toko online (Gambar 3). Hal ini penting untuk menunjukkan sisi sample produk secara baik dan jelas. 
Pembeli akan mudah tertarik jika foto produk menarik dipandang, karena ada nilai estetika tersendiri untuk suatu produk (Purwanto \& Veranita, 2018).

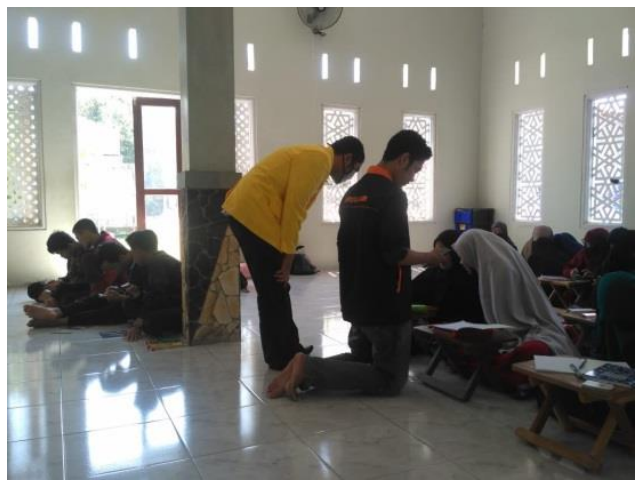

Gambar 3. Pendampingan pembuatan watermark foto produk

\section{Pendampingan Melalui Grup WhatsApp}

Kegiatan pendampingan melalui grup whatsapp dimulai pada hari Selasa, 25 Agustus hingga November 2020. Kegiatan ini dilaksanakan guna membantu para santri maupun pengurus yang kesulitan untuk menjual produknya atau mengalami kesulitan lainnya. Dengan kegiatan pembimbingan melalui grup whatsapp ini juga meminimalisir berbicara/berkontak langsung dengan melibatkan orang banyak. Pada Gambar 4, merupakan toko online yang dibuat oleh pengurus pondok dan para santri pada Shopee.

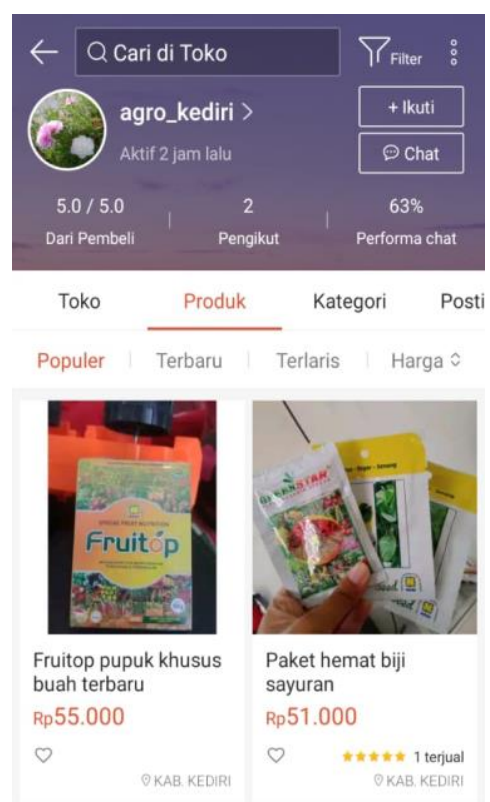

Gambar 4. Toko online di Shopee dan jenis produk

\section{Pendampingan dan Cek Berkala Perkembangan Akun Online}

Kegiatan pengabdian masyarakat ini dimulai dari pengenalan tentang digital marketing itu sendiri hingga ke tahap pemantauan sebuah akun online yang berhasil dibuat dan sebagai cikal bakal tumbuhnya toko-toko online lainnya. Kegiatan pendampingan dan cek berkala perkembangan akun online tetap dilakukan untuk membantu peningkatan kualitas dan kuantitas penjualan (Gambar 5). Pengecekan akun online secara berkala serta komunikasi dengan menggunakan aplikasi WhatsApp tetap dilakukan. Santri dan pengurus tetap mendiskusikan kendala-kendala yang muncul. Tim pengabdian juga melakukan pengecekan apakah iklan yang dimasukkan di aplikasi shopee sudah selalu update. Hal ini penting karena dengan updatenya iklan akan menambah kepercayaan konsumen untuk membeli di toko online yang dimiliki santri. Hal lain yang perlu di cek adalah apakah foto dan deskripsi produk yang dimasukkan ke marketplace Shopee sudah jelas. Hal ini berguna untuk mengurangi kesalahan dalam pengiriman produk. Pendampingan dilakukan secara berkala untuk mengatasi permasalahan yang terjadi. Peningkatan jumlah pesanan pada akun online terjadi. Awalnya 2-3 pesanan dalam sehari, meningkat menjadi 5-10 pesanan per hari.

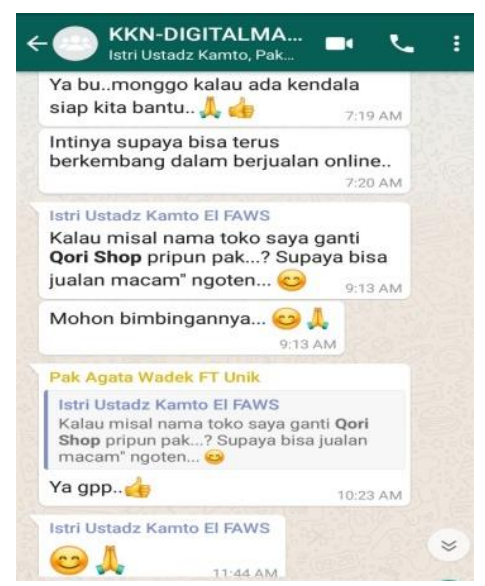

Gambar 5. Pendampingan melalui grup whatsapp

Setelah dilakukan pelatihan digital marketing dan serangkaian kegiatan yang lain, pengurus dan santri dapat melakukan penjualan produk di aplikasi Shopee dengan nama akun eLQe_Shop. Seperti terlihat pada Gambar 6, santri telah melakukan transaksi penjualan terlihat dari Gambar 6(a) sudah menyelesaikan tahapan penjualan hingga akhir. Pada Gambar 6(b), proses sudah sampai tahap pengemasan. Produk yang dijual berupa bibit, pupuk, dan busana muslim. Untuk produk yang terjual di akun eLQe_Shop seperti busana muslim 
dan pupuk sebagian besar dari distributor lain, sementara produk bibit bunga atau tanaman berasal dari pesantren. Untuk target kedepannya, diharapkan menambah jumlah akun sebanyak 2 akun online di aplikasi Shopee dan Bukalapak.

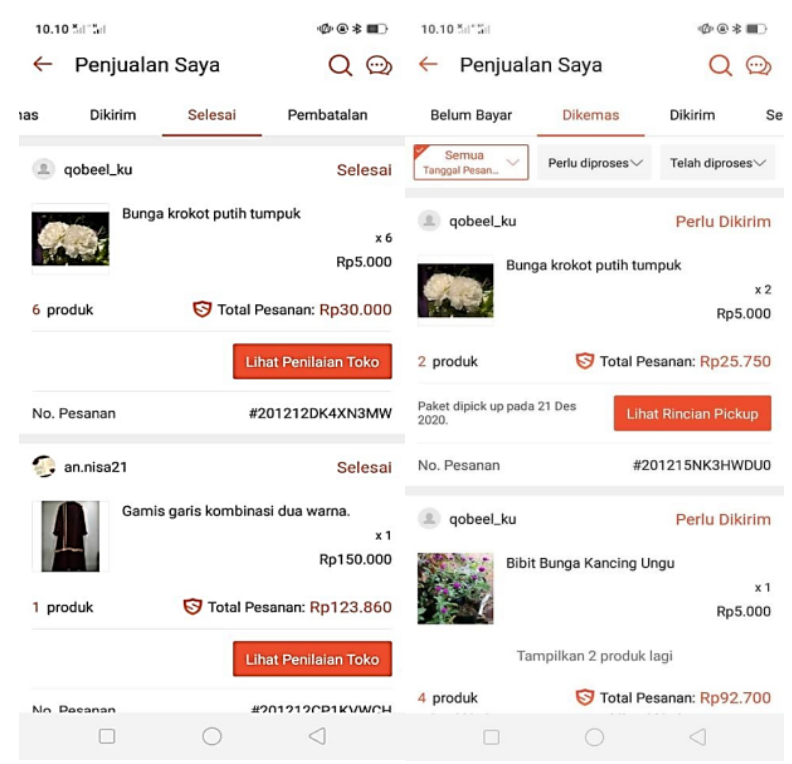

(a)

(b)

Gambar 6. Dokumentasi kegiatan penjualan di aplikasi Shopee. (a) Sudah selesai hingga tahap akhir. (b) Sampai tahap pengemasan

\section{KESIMPULAN}

Hasil kegiatan pengabdian masyarakat yang telah dilaksanakan ini terlihat bahwa santri dan pengurus pondok pesantren El Faws dapat mengikuti pelatihan dengan baik dan dapat langsung mempraktekkan materi yang disampaikan. Dengan adanya kegiatan ini, mampu meningkatkan perekonomian para santri dan pengurus di pesantren. Dengan meningkatnya penjualan melalui online, maka santri dan pengurus dirasa perlu untuk mempelajari pembukuan sederhana atau ilmu administrasi. Pelatihan mengenai pembukuan sederhana akan diikuti oleh pengurus dan santri yang terlibat dalam usaha bisnis online. Pelatihan ini akan memanfaatkan program Excel dan Microsoft word. Hal ini menjadi agenda berikutnya dari tim pengabdian masyarakat. Selain itu tim pengabdian masyarakat bermaksud mengadakan pelatihan pembuatan produk penunjang kebersihan seperti sabun cuci tangan dll, untuk menambah jenis atau item produk yang dijual di eLQe_Shop.

\section{UCAPAN TERIMA KASIH}

Kami ucapkan terima kasih kepada Universitas Kadiri, Pondok Pesantren El Faws serta semua pihak yang membantu pelaksanaan pengabdian masyarakat ini.

\section{DAFTAR PUSTAKA}

Agustin, C. A., \& Hellianto, G. R. (2020). Pengaruh Reputasi Terhadap Minat Beli Produk Skincare di Shopee. Business Economic, Communication, and Social Sciences (BECOSS) Journal, 2(1), 39-52. https://journal.binus.ac.id/index.php/BECOSS/article/vi ew/6050

Farell, G., Thamrin, T., \& Novid, I. (2019). Pelatihan Pemanfaatan Digital Marketing Dalam Pengembangan Pemasaran Dan Kewirausahaan UKM Pada Kota Sawahlunto. Suluah Bendang: Jurnal IImiah Pengabdian Kepada Masyarakat, 19(1), 42-47. https://doi.org/10.24036/sb.0310

Faris, M. I., Sembodo, G., Hasanah, L. U., \& Pramono, A. (2018). Pelatihan Sukses Berbisnis Online Memajukan Perekonomian Masyarakat Melalui Pemasaran Online Putat Jaya Surabaya. Jurnal Abdikarya: Jurnal Karya Pengabdian Dosen dan Mahasiswa, 1(1), 86-89. http://jurnal.untagsby.ac.id/index.php/abdikarya/article/view/2041

He, H., \& Harris, L. (2020). The impact of Covid-19 pandemic on corporate social responsibility and marketing philosophy. Journal of Business Research, 116 (May). https://doi.org/10.1016/j.jbusres.2020.05.030

Herhausen, D., Miočević, D., Morgan, R. E., Kleijnen, M. H. P., Luminy, D. De, \& Antoine, R. (2020). The digital marketing capabilities gap. Industrial Marketing Management, 90(March), 276-290. https://doi.org/10.1016/j.indmarman.2020.07.022

Jalal, A., \& Aziz, A. (2017). Pondok Pesantren dan Jihad: Studi Tentang Pembelajaran Konsep Jihad. Jurnal Penelitian \& Pendidikan Islam 5(1), 55-66. https://risetiaid.net/index.php/jppi/article/view/65

Luc, M. H., Tsang, S. W., Thrul, J., Kennedy, R. D., \& Moran, M. B. (2020). Content analysis of online product descriptions from cannabis retailers in six US states. International Journal of Drug Policy, 75, 102593. https://doi.org/10.1016/j.drugpo.2019.10.017

Punwana, D., Rahmi, R., \& Aditya, S. (2017). Pemanfaatan Digital Marketing Bagi Usaha Mikro, Kecil, Dan Menengah (UMKM) Di Kelurahan Malaka Sari, Duren Sawit. Jurnal Pemberdayaan Masyarakat Madani (JPMM), 1(1), 1-17. https://doi.org/10.21009/jpmm.001.1.01

Purwanto, Y., \& Veranita, M. (2018). Pelatihan Fotografi Dasar Bagi Pelaku Usaha Kecil Dan Menengah ( Ukm ) Kecamatan Lengkong Kota Bandung. Jurnal Dharma Bhakti Ekuitas. 02(02), 205-211. http://repository.ekuitas.ac.id/handle/123456789/427

Rahman, F., \& Mawardi, M. K. (2017). Strategi UMKM dalam membangun brand toko online di marketplace (Studi pada komunitas tokopedia di Kota Bekasi). Jurnal Administrasi Bisnis, 53(1), 39-48. http://administrasibisnis.studentjournal.ub.ac.id/index.p $\mathrm{hp} / \mathrm{jab} / \mathrm{article} / \mathrm{view} / 2180$

Susanti, E. (2020). Pelatihan Digital Marketing Dalam Upaya Pengembangan Usaha Berbasis Teknologi Pada Umkm Di Desa Sayang Kecamatan Jatinangor. Sawala: Jurnal pengabdian Masyarakat Pembangunan Sosial, Desa 
dan Masyarakat, 1 (2), 36-50.

https://doi.org/10.24198/sawala.v1i2.26588

Syafe'i, I. (2017). Pondok pesantren: Lembaga pendidikan pembentukan karakter. Al-Tadzkiyyah: Jurnal Pendidikan Islam, 8(1), 61-82. https://doi.org/10.24042/atjpi.v8il.2097

Wang, Y. (2020). Marketing innovations during a global crisis: A study of China fi rms' response to COVID-19. Journal of Business Research, 116(May), 214-220. https://doi.org/10.1016/j.jbusres.2020.05.029 